\title{
PERSPEKTIF HERMENEUTIKA RICOEUR MENYUSURI AGENDA TOLERANSI DI ORGANISASI ISLAM NAHDLATUL ULAMA
}

\section{The Perspective of The Ricoeur Hermeneutics in Search of Tolerance Agenda at The Islamic Organization of Nahdlatul Ulama}

\author{
1)*Said Romadlan, Ibnu Hamad, Effendi Gazali \\ ${ }^{1)}$ Universitas Muhammadiyah Prof. Dr. Hamka, Jakarta, Indonesia \\ ${ }^{2)}$ Universitas Indonesia, Depok, Indonesia \\ ${ }^{3)}$ Universitas Prof. Dr. Moestopo (Beragama), Jakarta, Indonesia \\ ${ }^{1)}$ Jalan Limau II Kebayoran Baru, Jakarta, Indonesia. \\ ${ }^{2)}$ Gedung A, Fakultas Ilmu Sosial dan Ilmu Politik, Kampus UI, Depok 16424, Indonesia. \\ ${ }^{3)}$ Kampus I: J1. Hang Lekir I/8 Gelora Jakarta, 10270, Indonesia.
}

Diterima 29 Januari 2020 / Disetujui 24 Agustus 2020

\begin{abstract}
The Perspective of the Ricoeur hermeneutics about tolerance at the Islamic organization Nahdlatul Ulama (NU) focuses on the interpretation process of $N U$ as an influential Islamic organization concerning tolerance to non-Muslims. The understanding of current tolerance is crucial amid strengthening the action of intolerances and discrimination in various forms of intimidation and assault on minority groups. In addition, the interpretation of the meaning of tolerance can be considered to be one of the triggers of radical action, especially when associated with issues of political leadership, the establishment of a place of worship, and so on. Therefore, the purpose of this article is to understand how the process of interpretation done by NU about tolerance toward non-Muslims. The Method in this study was the hermeneutics method of Paul Ricoeur, that emphasizing the interpretation of the text with the distanciation process between text and the reader. The results show that the interpretation process of tolerance is based on the language (verses) of the Qur'an surat al-Hujurat verse 13 "Lita'arafu", which means to know each other. In the process of language distancing into discourse, the verse is understood by NU tolerances as Ukhuwah Wathaniyah, the Brotherhood of country and nation. The practice of discourse shows that the interpretation of $N U$ is motivated by the reality that the plurality of religion as Sunnatullah, and its practice in the context of muamalah, and to realize the treatise of Islam as a religion of rahmatan lil-aalamin. The contextual interpretation of $N U$ is based on the importance of maintaining the integrity of the Indonesia. The Interpretation of this tolerance to non-Muslims can be used as a counter-discourse of the interpretations of radical Islamist groups that considers non-Muslims to be enemies so that they must be affected even.
\end{abstract}

Keywords: Hermeneutics, NU, Tolerance, Ukhuwah Wathaniyah

\begin{abstract}
ABSTRAK
Perspektif hermeneutika Ricoeur tentang toleransi di organisasi Islam Nahdlatul Ulama (NU) memfokuskan pada proses penafsiran NU sebagai organisasi Islam berpengaruh mengenai toleransi terhadap nonmuslim. Pemahaman atas toleransi saat ini sangat penting di tengah menguatkan tindakan intoleran dan diskriminasi dalam berbagai bentuk intimidasi dan penyerangan terhadap kelompok-kelompok minoritas. Selain itu, penafsiran mengenai makna toleransi ini dapat dianggap menjadi salah satu pemicu tindakan radikal, terutama bila dikaitkan dengan isu-isu kepemimpinan politik, pendirian tempat ibadah, dan sejenisnya. Studi ini bertujuan untuk mendalami proses penafsiran mengenai toleransi terhadap non-muslim oleh organisasi Islam NU. Studi ini menggunakan perspektif dan metode hermeneutika Ricoeur yang menfokuskan pada otonomi teks dalam proses penafsiran dan distansiasi makna antara pembuat teks dan pembaca. Kajian ini menghasilkan temuan bahwa dalam proses penafsiran tentang toleransi terhadap non-muslim NU merujuk pada kata "lita'arafu" dalam surat alHujurat: 13, yang berarti supaya saling mengenal. Melalui distansiasi dari bahasa ke diskursus, kata "lita'arafu"
\end{abstract}


dipahami NU dalam bentuk $u$ khuwah wathaniyah, yakni persaudaraan sebangsa dan senegara. Praktik diskursus menunjukkan bahwa penafsiran NU tersebut dilatarbelakangi realitas bahwa pluralitas agama sebagai sunnatullah, dan praktiknya dalam konteks muamalah, serta untuk mewujudkan risalah Islam sebagai agama rahmatan lil-aalamin. Secara kontekstual penafsiran NU dilandasi kepentingan menjaga keutuhan NKRI. Penafsiran tentang toleransi terhadap non-muslim NU ini dapat dijadikan sebagai wacana tandingan atas penafsiran kelompok-kelompok Islam radikal yang menganggap non-muslim sebagai musuh sehingga harus dimusuhi bahkan diperangi.

Kata Kunci: Hermeneutika, NU, Toleransi, Ukhuwah Wathaniyah

*Korespondensi penulis:

Email: saidromadlan@uhamka.ac.id

\section{PENDAHULUAN}

Permasalahan toleransi antarumat beragama, baik dalam konteks global maupun lokal Indonesia akan terus muncul. Hal ini karena adanya realitas bahwa dunia ini dihuni bukan hanya beragam agama dan kepercayaan tapi juga beragam suku, ras, dan golongan. Toleransi ini menjadi kunci keberlangsungan kehidupan sosial antar-unsur yang berbeda agar tetap berlangsung secara harmonis, dan damai. Maka, masalah toleransi menjadi penting untuk dikaji dari berbagai perspektif untuk dijadikan acuan dan bahan pemecahan masalah yang berkaitan dengan relasi antarumat beragama, khususnya di Indonesia sebagai bangsa dengan beragam agama.

Toleransi secara terminologis dapat diartikan sebagai sikap membebaskan orang atau kelompok lain untuk bertindak seperti yang diinginkan. Dalam konteks masyarakat sipil, toleransi diartikan sebagai kemampuan untuk hidup dalam perbedaan (Mouritsen, 2003). Sedangkan dalam konteks toleransi antar pengikut agama, toleransi adalah saling membebaskan dan menghargai antar-pengikut agama dan memelihara situasi dan kondisi yang kondusif bagi pengikut agama lain untuk melakukan peribadatan dan perintah agamanya tanpa dirintangi oleh pengikut agama lain (B. Arifin, 2016; Jamrah, 2015).

Pada realitasnya, toleransi ini tidak serta merta berjalan mulus tanpa konflik. Kasus-kasus seperti pelarangan beribadah, penyerangan dan perusakan tempat ibadah masih sering terjadi di daerah-daerah misalnya di Sampang, Madura dan di Ciukesik, Bogor. Bahkan konflik berdarah antaragama pernah terjadi di Ambon Maluku,
Poso, dan Kalimantan Barat (Al Qurtuby, 2013).

Faktor-faktor yang memengaruhi masalah toleransi beragama justru banyak dari eksternal non-agama seperti politisasi agama untuk kepentingan kekuasaan. Faktor lain yang memengaruhi toleransi adalah faktor ekonomi, seperti yang terjadi di Ambon dan Poso. Faktor globalisasi juga dapat menjadi pemicu sikap intoleransi agama, di mana globalisasi menggerus nilai-nilai tradisional, termasuk agama, yang kemudian memicu perlawanan dalam bentuk tindakan radikal untuk mempertahankan tradisi (Mu'ti, 2016).

Masalah toleransi beragama semakin menyeruak pasca tumbangnya kekuasaan Orde Baru pimpinan Soeharto pada 1998. Hal ini ditandai dengan bangkitnya kembali kelompokkelompok yang mengatasnamakan agama yang dianggap tidak toleran, temasuk Majelis Ulama Indonesia (MUI) (Hefner, 2013). Selain itu, pasca Orde Baru kekerasan dalam bentuk antiminoritas dan anti-Kristen meningkat tajam, termasuk konflik antaragama di Ambon, pelarangan dan penyerangan pendirian Gereja di Bogor, dan penyerangan terhadap Ahmadiyah, bahkan penolakan terhadap ideologi Pancasila yang dilakukan kelompok Islam radikal (Hefner, 2017).

Ancaman terhadap toleransi beragama di Indonesia semakin nyata dengan adanya penyerangan pendukung Ahmadiyah di Monas pada Juni 2008, dan penyerangan terhadap perkampungan Ahmadiyah di Ciampea, Bogor, Jawa Barat pada Januari 2011, karena dianggap menyimpang dari Islam oleh kelompok Islam ortodok (Crouch, 2011). Fenomena menguatkan tindakan intoleransi beragama ini merupakan bagian dari conservative turn, titik 
balik kebangkitan kelompok-kelompok Islam radikal pasca Orde Baru (Assyaukanie, 2013).

Meskipun kekerasan atas nama agama tersebut dilakukan oleh kelompok-kelompok yang menyebut dirinya Islam, namun pada prinsipnya Islam sebagai agama mayoritas di Indonesia secara teologis merupakan agama yang penuh dengan nilai-nilai toleransi dan kerukunan antar pengikut agama. Terdapat 114 sampai 140 ayat-ayat al-Qur'an yang mengandung nilai toleransi (Safrodin, 2019). Islam memandang sama antar pengikut agama langit (samawi) dan agama bumi (non-samawi), mereka diposisikan setara sebagai umat manusia yang terikat dengan ikatan persaudaraan universal sebagai ciptaan Tuhan. Dalam hidup dan berinteraksi dengan pengikut agama lain, toleransi dalam Islam ditunjukkan dengan memberi kebebasan pengikut agama lain melaksanakan ibadah dan perintah agamanya dengan aman dan tenang sepanjang sesuai dengan ketentuan dan tidak menyebabkan kekacauan dan menjaga kepentingan umum (Bakar, 2015; Mursyid, 2016).

Permasalahan toleransi beragama ini juga dapat muncul dari penafsiran ayat-ayat toleransi tersebut. Hal ini karena perbedaan pemahaman mengenai toleransi, terutama terhadap non-muslim karena setiap orang dan kelompok memiliki subyektifitas masingmasing yang didasarkan pada kepentingan yang ada. Misalnya pemahaman tentang toleransi terhadap non-muslim yang berbeda dalam pandangan tokoh Islam seperti Hamka dan Nurcholis Madjid tentang selamat Hari Natal (Gunawan, 2015; Manan, 2016).

Salah satu organisasi Islam yang dikenal moderat dan toleran di Indonesia adalah Nahdlatul Ulama (NU), selain juga Muhammadiyah. Menurut Greg Barton, NU adalah gerakan sosial progresif, di mana mereka berada di lingkungan yang plural, dan tetap optimis bahwa Islam dapat sejalan dengan masyarakat modern (Barton, 2014). Tradisi moderat dan toleran NU ini sudah tertanam lama, dan inilah yang menyebabkan NU sebagai organisasi tidak bisa disusupi oleh ekspansi kelompok-kelompok Islam radikal seperti Hizbut Tahrir Indonesia (HTI), Partai
Keadilan Sejahtera (PKS), dan lain-lain (Wahid \& Taylor, 2008).

Moderatisme NU dikenal melalui doktrin ajaran ahlussunnah wal jamaah (Aswaja) yang digagas oleh salah seorang tokoh NU yakni KH. Ahmad Siddiq, di mana karakteristik Islam Sunni diwujudkan oleh NU dengan sikap moderat (tawasuth), adil (i'itidal), seimbang (tawazzun), dan toleran (tasamuh), serta tolong menolong (ta'awun) (Burhani, 2012). Menurut Hannese, pandangan NU sebagai organisasi Islam toleran, moderat, dan egaliter serta nasionalis inilah yang mampu mengatasi dan meredam konflik antaragama di berbagai daerah di Indonesia (Hannase, 2017). Termasuk berperan dalam menjaga toleransi di Papua, di mana NU memerankan peran penting menjaga harmoni antaragama di sana setelah peristiwa Tolikara dan Kowe Barat (Ridwan, 2020).

Maka dalam konteks memahami toleransi beragama ini, terutama memahami penafsiran terhadap ayat-ayat al-Qur'an yang berkaitan dengan toleransi menjadi penting. Untuk itu, kajian ini menggunakan perspektif hermeneutika, yakni kajian filsafat mengenai penafsiran makna. Menurut Jenet Wolff, hermeneutika secara sederhana berarti penafsiran (interpretation), atau penafsiran pemahaman. Sebagai tradisi, hermeneutika menaruh perhatian pada penafsiran terhadap teks, obyek budaya, periode sejarah, dan pandangan dunia (Wolff, 1975).

Dalam kajian ini, penafsiran dan pemahaman atas teks secara lebih kontekstual mengenai toleransi terhadap non-muslim dilakukan oleh NU sebagai salah organisasi Islam moderat di Indonesia. Berkaitan dengan penafsiran untuk pemahaman mengenai toleransi terhadap non-muslim ini, maka kajian ini menggunakan Teori Interpretasi Paul Ricoeur dan Teori Hermeneutika.

Fokus utama Teori Interpretasi Paul Ricoeur adalah teks yang mempunyai kebebasan (otonomi teks). Artinya, makna sebuah teks tidak lagi tergantung pada maksud pembuat teks, tapi pada pembaca teks. Maka dari itu, teori interpretasi dalam membahas 
mengenai otonomi teks ini menggabungkan secara bersamaan antara pemahaman (understanding) dan penjelasan (explanation) dalam satu proses penafsiran. Interpretasi ini menjadi persoalan utama dalam hermeneutika (Ricoeur, 2006). Melalui interpretasi dunia teks bertemu dengan dunia pembaca untuk membentuk makna baru. Menurut Tan, dkk, dalam pandangan Ricoeur, hubungan antara menjelaskan (explanation) dan memahami (understanding) dan sebaliknya antara memahami dan menjelaskan merupakan sebuah lingkaran hermeneutika (hermeneutics circle) (Tan et al., 2009).

Gagasan utama Teori Interpretasi adalah mengenai teks sebagai sebuah karya yang otonom, di mana makna sebuah teks tidak lagi tergantung pada maksud pembuatnya (otonomi teks). Untuk memahami sebuah teks tidak diperlukan lagi memahami maksud pengarangnya, tetapi lebih dengan menafsirkan sendiri makna teks tersebut. Otonomi teks ini menyebabkan substansi teks terlepas dari cakrawala pembuatnya. Melalui distansiasi, dunia teks dapat meluas melampaui dunia pembuatnya. Proses pemisahan antara teks dengan maksud pengarang ini dalam teori Interpretasi Ricoeur disebut distansiasi atau penjarakan (Ricoeur, 2006).

Distansiasi (distanctiation) terjadi ketika individu secara aktif menafsirkan sendiri tekstual dan nontekstual dari sistem simbolik (bahasa). Distansiasi merupakan konsep baru dalam dunia tekstualitas, yang menunjukkan hubungan antara pemahaman diri sendiri dengan dunia teks yang terhampar (Petrovici, 2013). Dalam praktiknya, distansiasi ini terjadi dalam proses penafsiran melalui dua tahap, yakni ketika bahasa berubah menjadi diskursus, yang disebut sebagai distansiasi pertama, dan ketika diskursus berubah menjadi teks (tekstualitas), yang merupakan distansiasi kedua (Magnis-Suseno, 2016).

Ricoeur dalam teori Interpretasi paling serius dalam memperhatikan polemik mengenai dikotomi antara penjelasan (explanation) dan pemahaman (understanding). Ricoeur mencoba mempertemukan dikotomi tersebut dengan memposisikan keduanya secara berbeda berbeda namun saling melengkapi dalam hal fungsinya. Dalam pandangan Dilthey, 'penjelasan' mengacu kepada model eksplanasi ilmu alam dan diterapkan pada disiplin historis oleh mazhab positivis. Di sisi lain, 'penafsiran' merupakan bentuk derivasi dari pemahaman yang dipandang oleh Dilthey sebagai sikap fundamental dalam disiplin ilmu-ilmu kemanusiaan (Ricoeur, 2006; Tan et al., 2009).

Hermeneutika merupakan konsep yang diambil dari kata Yunani yakni hermeneuein dan hermenia yang memilik arti "menafsirkan". Tujuan hermeneutika sebagai memahami adalah kesepahaman. Menurut Richard E. Palmer, dalam penggunaan aslinya kata hermeneuein dan hermenia mempunyai arti yang dapat disepadankan dengan kata "penafsiran" (to interpret) (Palmer, 2005). Menurut Elizabeth Anne Kinsella, hermeneutika adalah seni menafsirkan. Pendekatan hermeneutika memiliki beberapa karakteristik, yaitu: mencari pemahaman daripada penjelasan, pengetahuan ditentukan pada lokasi penafsiran, mengenalkan peran bahasa dan historisitas dalam penafsiran, memandang pengukuran sebagai pembicaraan, dan nyaman dengan ambiguitas (Kinsella, 2006).

Studi-studi yang terkait dengan studi ini yang pernah dilakukan antara lain pertama, mengkaji mengenai hermeneutika kerukunan Farid Esack yang mengedepankan pluralisme dan inklusivisme beragama (Muhtarom, 2017). Kedua, mengkaji mengenai interaksi Muhammadiyah dengan masalah pluralisme agama (Mu'ti, 2016). Ketiga, mengkaji fatwa ulama tentang mengikuti perayaan Natal. Sebagian ulama melarang umat Islam merayakan Natal, tapi sebagian ulama lain memperbolehkan (Manan, 2016). Keempat, mengenai persepsi santri dan kiai Muhammadiyah dan NU terhadap pluralisme, di mana mereka menerima secara sosiologis, tapi menolak secara teologis (Z. Arifin \& Yu'timaalahuyatazaka, 2017). Kelima, mengenai diskursus ayat-ayat yang berkaitan dengan toleransi dan ayat-ayat yang berhubungan dengan perang dalam al-Qur'an. Ditemukan 114 ayat-ayat toleransi dan 22 ayat perintah perang (Safrodin, 2019). Keenam, studi tentang penafsiran aktivis muda NU mengenai toleransi di Malang Jawa Timur, di mana hasil kajiannya menunjukkan aktivis muda NU lebih toleran (Maksum et al., 2019).

Kebaruan (novelty) dari studi ini dibanding dengan beberapa studi di atas terletak 
pada teks yang diinterpretasikan, dan tentu saja fokus kajiannya. Pada studi ini teks yang ditafsirkan adalah dalam bentuk bahasa (ayat) al-Qur'an, yang melalui proses distansiasi membuat maknanya menjadi otonom pada tingkat diskursus dan tekstualitas. Dengan penafsiran yang menggunakan distansiasi, dapat melahirkan pemahaman-pemahaman baru yang lebih kontekstual dari bahasa (ayat) al-Qur'an, dan lebih selaras dengan nilai-nilai yang diajarkan dalam agama Islam yakni agama yang membawa kerahmatan bagi sekalian alam.

Kajian ini memfokuskan pada penafsiran mengenai toleransi terhadap nonmuslim oleh NU sebagai salah satu organisasi Islam moderat di Indonesia yang berpengaruh. Identifikasi masalah dalam kajian ini adalah bagaimana penafsiran NU sebagai organisasi Islam moderat mengenai toleransi terhadap non-muslim dalam perspektif hermeneutika.

Tujuan kajian ini adalah untuk memahami penafsiran NU sebagai organisasi Islam mengenai toleransi terhadap non-muslim. Adapun manfaat kajian ini secara akademik dapat berkontribusi pada pengembangan Teori Interpretasi, terutama mengenai distansiasi dalam penafsiran. Selain itu secara sosial dapat memberikan pemahaman yang lebih kontekstual kepada masyarakat mengenai toleransi terhadap non-muslim, sekaligus menjadikan hasil penafsiran NU sebagai organisasi Islam ini sebagai kontra-diskursus atas pemahaman mengenai hubungan dengan non-muslim. Selama ini penafsiran tentang toleransi cenderung dipahami secara tekstual sehingga seringkali memicu tindakan-tindakan intoleran dalam bentuk diskriminasi dan penyerangan secara fisik, terutama oleh kelompok-kelompok Islam radikal.

\section{METODE PENELITIAN}

Kajian ini menggunakan pendekatan kualitatif yang menekankan pada subyektifitas peneliti dalam menafsirkan data (teks). Metode yang digunakan adalah metode hermeneutika fenomenologi Ricoeur. Dalam hermeneutika untuk menelaah suatu teks, maka makna teks tersebut mesti diletakkan di luar dari perspektif pembuatnya (Bryman, 2012). Teks dalam studi ini mengacu kepada ayat-ayat al-Qur'an yang dirujuk kalangan NU untuk memahami toleransi. Pada kajian ilmu komunikasi hermeneutika merupakan paradigma baru yang menjadi pilihan lain dari paradigma sebelumnya, yaitu paradigma transmisi yang selama ini dianggap mendominasi dalam kajian-kajian ilmu komunikasi (Radford, 2005). Hermeneutika Ricoeur sangat menekankan pada otonomi teks atau distansiasi dengan penjelasan dan pemahaman dalam penafsiran atas teks (Tan et al., 2009).

Subyek kajian ini adalah organisasi Islam Indonesia, yakni NU yang dipandang sebagai organisasi Islam moderat dan merupakan salah satu kekuatan yang mewarnai corak ke-Islaman Indonesia. Sebagai organisasi, NU berdiri pada tahun 1926 oleh KH. Hasyim As'ary di Surabaya, Jawa Timur, dan memiliki basis pesantren dan pedesaan (Azra, 2005). NU telah lama dikenal sebagai organisasi Islam moderat dan toleran di Indonesia. Bersama-sama Muhammadiyah, NU telah mampu menunjukkan landscape Islam Indonesia yang menjadi formula Islam di masa depan (Arifianto, 2017; Hilmy, 2013).

Metode pengumpulan data dilakukan melalui studi kepustakaan dan wawancara secara mendalam (indepth interview). Dokumen yang dianalisis adalah dokumendokumen resmi organisasi yang meliputi keputusan hasil muktamar, musyawarah nasional, keputusan Lembaga Bathsul Masail PBNU, dan beberapa tulisan di media resmi organisasi. Sedangkan wawancara mendalam dilakukan terhadap lima pengurus/aktivis NU, yaitu Helmy Faishal Zaini (Sekretaris Jenderal Pengurus Besar Nahdlatul Ulama), Sarmidi (Sekretaris Lembaga Bahtsul Masail PBNU), Khamami Zada (Wakil Ketua LAKPESDAM PBNU), Alissa Wahid (Sekretaris Lembaga Kemaslahatan Keluarga PBNU), dan Syafiq Ali (Redaktur NU Online). Mereka dipilih karena posisi dan pengetahuan mereka dianggap bisa mewakili organisasi untuk memahami konteks penafsiran NU sebagai organisasi Islam tentang toleransi terhadap non-muslim.

Adapun analisis data dilakukan dengan analisis teks yang menggunakan analisis hermeneutika fenomenologi Ricoeur yang menekankan pada proses penafsiran yang didasarkan atas pengalaman, yang meliputi analisis teks (semantik), analisis refleksi, dan analisis konteks untuk memahami konteks penafsiran dan faktor-faktor yang menentukan penafsiran. 


\section{HASIL DAN PEMBAHASAN}

\section{Analisis Hermeneutika}

Penafsiran NU tentang toleransi terhadap non-muslim merujuk pada al-Qur'an surat al-Hujurat ayat 13 yang menganjurkan untuk saling mengenal, dan surat alMumtahanah ayat 8 yang memerintahkan untuk berbuat baik dan berlaku adil kepada siapapun. Penafsiran NU tentang toleransi terhadap nonmuslim dilakukan dengan menggunakan analisis semantik (teks) dan interpretasi mendalam sebagai berikut:

1. Penjelasan (Explanation): menganalisis teks menggunakan semantik-mendalam (indepth-semantic), yang meliputi:

a. Latar: bagian teks untuk memahami latar belakang teks dibuat.

Latar belakang NU menafsirkan toleransi terhadap non-muslim adalah karena adanya sebuah kenyataan bahwa manusia dalam beragama dan berkeyakinan secara beragam dan berbeda-beda adalah ketentuan Allah Swt. (sunnatullah), yang tidak dapat dihindari. Latar belakang penafsiran NU ini tercantum dalam Wawasan NU tentang Pluralitas Bangsa sebagaimana diputuskan pada Muktamar NU ke-29 tahun 1994 di Cipasung Tasikmalaya.

Dalam keputusan tersebut dinyatakan bahwa NU secara penuh memahami realitas kemajemukan (pluralitas) bangsa Indonesia dan mempercayainya sebagai ketentuan Allah Swt. Kemajemukan masyarakat yang meliputi kemajemukan agama, suku, kultur dan lain sebagainya merupakan sebuah kenyataan dan menjadi rahmat dalam sejarah Islam sejak zaman Nabi Muhammad Saw.

b. Detil: bagian teks yang menunjukkan pentingnya teks dengan menyajikan teks yang menguntungkan pembuat teks secara lebih mendetail.

Dalam pandangan NU toleransi terhadap non-muslim dapat dipahami sebagai ukhuwah insaniyah (persaudaraan atas dasar kemanusiaan) yang masing-masing harus saling memelihara hak-haknya, saling menolong, berlaku adil, dan tidak berbuat dzalim kepada yang lain. Secara mendetail, pandangan NU tersebut ditegaskan melalui keputusan Komisi Bahtsul Masail pada Konferensi NU Wilayah Jawa Timur di Pondok Pesantren Lirboyo Kediri, tahun 2018.

Dalam keputusan tersebut dinyatakan latar belakang agama yang berbeda tidak boleh digunakan sebagai alasan untuk berbuat tidak baik, saling memusuhi dan memerangi pengikut agama lain. Maka dari itu, dasar relasi antara umat muslim dan non-muslim dalam pandangan NU bukan peperangan dan pertikaian, tetapi hubungan yang dilandasi dengan perdamaian dan hidup bersama dengan saling menghormati.

Selain itu, toleransi dengan nonmuslim dipahami NU lebih pada konteks kebangsaan atau ke-Indonesiaan yakni ukhuwah wathaniyah dalam wujud persaudaraan kebangsaan yang tidak memandang pada latar belakang keagamaan dan kepercayaannya, serta tidak melihat latar belakang sektarian lainnya. Pemahaman NU ini ditegaskan secara mendetil pada keputusan Komisi Bahtsul Masail pada Konferensi NU Wilayah Jawa Timur di Pondok Pesantren Lirboyo Kediri tahun 2018.

c. Maksud: bagian teks yang menunjukkan maksud pembuat teks dengan menyajikan teks secara lebih nyata.

Pemahaman NU mengenai toleransi terhadap non-muslim sebagai wujud ukhuwah wathaniyah atau tata hubungan sesama berkaitan dengan persaudaraan se-bangsa dan se-tanah air. Tata hubungan ini mencakup masalahmasalah yang berkaitan dengan muamalah (sosial, politik, budaya). Dalam konteks muamalah ini setiap warga negara mempunyai derajat dan tanggung jawab yang sama dalam mengusahakan kesejahteraan hidup secara bersama-sama.

Maksud pemahaman NU tesebut diputuskan pada Muktamar NU ke-29 tahun 1994 di Cipasung Tasikmalaya bahwa wawasan NU tentang Pluralitas Bangsa merupakan sikap toleransi yang berkaitan dengan ukhuwah wathaniyah meliputi: 
a. Sikap akomodatif: bersedia mengakomodasi berbagai kepentingan, pandangan dan aspirasi dari berbagai kalangan;

b. Sikap selektif: cerdas dan kritis dalam menentukan kepentingan yang terbaik dan yang penuh kedamaian (ashlah) dan bermanfaat (anfa') dari pilihanpilihan yang tersedia;

c. Sikap integratif: bersedia menyesuaikan, menyerasikan dan menyetarakan kepentingankepentingan dan aspirasi secara tepat, adil, dan seimbang;

d. Sikap Kooperatif: bersedia untuk hidup berdampingan dan bekerja bersama dengan siapapun dalam konteks muamalah dan bukan pada konteks ibadah.

d. Praanggapan: bagian teks yang menunjukkan makna teks dengan menyajikan pernyataan yang sudah dianggap benar adanya.

NU juga memiliki praanggapan bahwa batas-batas toleransi dan menjaga kerukunan dengan pengikut umat beragama lain yang dalam praktiknya dilarang melewati batas-batas yang ditentukan. Praanggapan NU ini dicetuskan pada Keputusan Komisi Bahtsul Masail pada Konferensi NU Wilayah Jawa Timur di Pondok Pesantren Lirboyo Kediri tahun 2018, sebagai berikut:

a. Tidak melanggar batas keimanan (akidah) sehingga terperosok dalam kekafiran seperti mengikuti ritual agama lain yang bertujuan mensyiarkan kekafiran;

b. Tidak melanggar batas Syariah Islam sehingga terperosok dalam hal yang diharamkan, seperti menggunakan simbol-simbol yang serupa dengan agama lain yang bertujuan menyemarakkan hari raya agama lain.

2. Pemahaman (Understanding): memahami teks-teks melalui interpretasi-mendalam (indepth interpretation):

a. Distansiasi/penjarakan: terlepasnya substansi/makna teks dari maksud pembuatnya.

NU secara lebih jelas pada gambar 1.
NU menafsirkan toleransi terhadap non-muslim adalah karena adanya sebuah kenyataan bahwa manusia dalam beragama dan berkeyakinan secara beragam dan berbeda-beda adalah ketentuan Allah Swt. (sunnatullah), yang tidak dapat dihindari. Penafsiran NU tersebut merujuk kepada al-Qur'an surat al-Hujurat ayat 13 yang artinya yang di dalamnya mengandung seruan untuk saling mengenal antarmanusia yang memiliki latar belakang yang berbeda.

Dalam distansiasi atau penjarakan, proses pemahaman NU tentang toleransi dengan non-muslim dapat dijelaskan melalui proses penjarakan berikut ini:

Distansiasi pertama: proses distansiasi dari bahasa menjadi diskursus. Bahasa "lita'arafu" yang artinya "supaya saling mengenal" sebagaimana tercantum dalam Surat alHujurat ayat 13 tersebut, dalam diskursus dipahami sebagai sunnatullah. Artinya, toleransi terhadap non-muslim merupakan keharusan karena adanya realitas perbedaan dalam beragama dan keyakinan sebagai sebuah keniscayaan yang tidak akan bisa dihapuskan.

Distansiasi kedua: diskursus menjadi teks (tekstualitas). Dalam distansiasi ini, diskursus tentang ukhuwah insaniyah (persaudaraan kemanusiaan) ditafsirkan sebagai ukhuwah wathaniyah (persaudaraan kebangsaan). Toleransi dengan nonmuslim sebagai wujud ukhuwah wathaniyah atau tata hubungan sesama berkaitan dengan persaudaraan sebangsa dan se-tanah air. Tata hubungan ini mencakup masalah-masalah yang berkaitan dengan muamalah (sosial, politik, budaya). Dalam konteks muamalah ini setiap warga negara mempunyai derajat dan tanggung jawab yang sama dalam mengusahakan kesejahteraan hidup secara bersamasama (Muktamar NU ke-29 tahun 1994 di Cipasung Tasikmalaya).

Proses distansiasi penafsiran tentang toleransi terhadap non-muslim

b. Rujukan/substansi teks: makna teks tidak lagi berada di balik teks tetapi terhampar dan dibentangkan di depan dunia teks. 


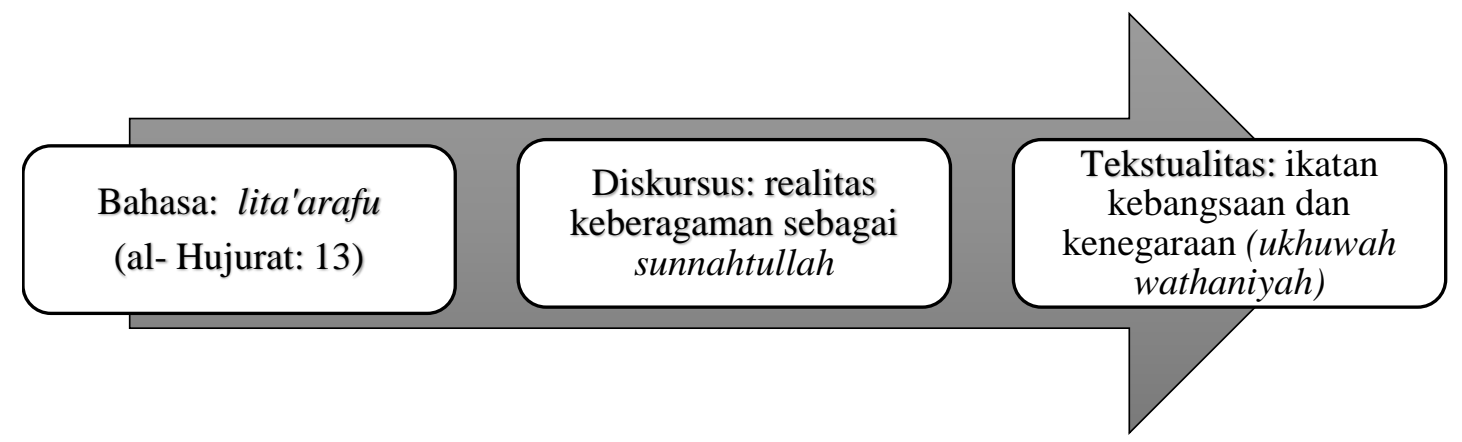

Gambar 1.

Distansiasi Penafsiran NU mengenai toleransi terhadap non-muslim. (Sumber: Diolah Penulis)

NU dalam menafsirkan toleransi terhadap non-muslim merujuk kepada surat al-Hujurat ayat 13 , khususnya pada teks (bahasa) litaarafuu (agar saling mengenal). Dalam menafsirkan teks tersebut NU tidak membatasi hanya dalam konteks saling mengenal antara laki dan perempuan, atau antarsuku dan bangsa, namun NU memahaminya secara lebih substantif dan dalam konteks yang lebih luas. NU menafsirkan lita'arafu sebagai teks yang dibentangkan sebagai persaudaraan kemanusian (ukhuwah insaniyah) yang universal dan persaudaraan kebangsaan (ukhuwah wathaniyah).

Persaudaraan kemanusiaan (ukhuwah insaniyah) sebagai bentuk penafsiran substantif NU mengenai toleransi terhadap non-muslim memposisikan NU sebagai pihak yang harus saling memahami hak-hak dengan kelompok lain, saling menolong, bertindak adil dan tidak melakukan kedzaliman terhadap pihak lain. Dalam keputusan Komisi Bahtsul Masail pada Konferensi NU Wilayah Jawa Timur di Pondok Pesantren Lirboyo Kediri tahun 2018, dinyatakan bahwa Islam sebagai agama yang mengajarkan keselamatan dalam menjalin relasi dan berinteraksi secara sosial dengan siapapun, baik dengan sesama muslim ataupun dengan non-muslim. Dalam pandangan NU, setiap muslim harus menampilkan dirinya dengan akhlak yang baik (akhlaq al karimah), perkataan yang lemah lembut, dan sikap sopan santun, serta penuh kasih sayang (rahmah).

Selain itu, NU juga menafsirkan teks (bahasa) lita'arafu sebagai rujukan pemahaman mengenai toleransi terhadap non-muslim secara substantif dalam ukhuwah wathaniyah (persaudaraan kebangsaan) yang tidak terikat pada agama dan kepercayaan yang berbeda dan batas-batas sektarian. Penafsiran NU ini merujuk kepada keputusan Komisi Bahtsul Masail pada Konferensi NU Wilayah Jawa Timur di Pondok Pesantren Lirboyo Kediri tahun 2018, bahwa Indonesia sebagai bangsa dipersatukan karena keinginan, cita-cita, serta tekad yang sangat kuat untuk membangun masa depan dan kehidupan bersama-sama sebagai sesama warga negara dalam naungan Negara Kesatuan Republik Indonesia (NKRI). Setiap elemen dari bangsa Indonesia dipersatukan dan meleburkan diri dalam sebuah persaudaraan kebangsaan (ukhuwah wathaniyah), yang terbebas dari latar belakang agama dan primordial lainnya yang berbeda.

c. Subyektifitas: dalam proses memahami dilakukan dengan membukakan diri (refleksi) melalui pendakuan dunia yang disodorkan dan yang dibentangkan oleh penafsiran.

Pada level subyektifitas ini, NU sudah menetap hasil penafsirannya tentang toleransi terhadap non-muslim yang merujuk kepada Surat al-Hujurat ayat 13, dalam bentuk persaudaraan kebangsaan (ukhuwah wathaniyah) 
sebagai bagian yang melekat dalam NU dan menjadi identitas NU sebagai organisasi Islam. Subyektifitas penafsiran NU ini adalah hasil refleksi yang kemudian dijadikan sebagai pendakuan (eksistensi diri) NU dalam konteks interaksi NU dalam bertoleransi dengan non-muslim. Tujuan pendakuan
NU tersebut adalah untuk memajukan bangsa dan menjaga keutuhan NKRI.

Secara lebih jelas analisis hermeneutika (penjelasan dan pemahaman) tentang toleransi dengan non-muslim dalam pandangan $\mathrm{NU}$ dideskripsikan pada gambar 2 mengenai model Hermeneutika Ricoeur.
PENJELASAN (Explanation):

a. Latar: toleransi terhadap non-muslim sebagai keniscayaan (sunnatullah).

b. Detil: toleransi dengan non-muslim dalam wujud ukhuwah insaniyah (persaudaraan kemanusiaan) yang dilandasi asas perdamaian dan hidup harmonis.

c. Maksud: toleransi terhadap nonmuslim dipahami dalam hubungan sesama dengan persaudaraan kebangsaan (ukhuwah wathaniyah).

d. Praanggapan: toleransi dengan nonmuslim penerapannya tidak boleh melampau batas-batas dan prinsipprinsip ajaran Islam.
PEMAHAMAN (Understanding):

a. Distansiasi:

- Bahasa: lita'arafu (saling mengenal).

- Diskursus: toleransi dengan nonmuslim sebagai sebuah keniscayaan (sunnatullah).

- Tekstualitas: toleransi dengan nonmuslim dengan wujud ukhuwah wathaniyah (persaudaraan kebangsaan).

b. Rujukan/substansi teks: memahami teks lita'arafu sebagai ukhuwah wathaniyah.

c. Subyektifitas (penafsiran): toleransi terhadap non-muslim sebagai ukhuwah insaniyah dan ukhuwah watahniyah untuk membangun masa depan Indonesia dan menjaga keutuhan NKRI.

Gambar 2.

Analisis Hermeneutika Ricoeur mengenai Toleransi terhadap non-Muslim menurut NU (Sumber: Diolah Penulis)

\section{Analisis Refleksi}

Pemahaman NU mengenai toleransi terhadap non-muslim dalam bentuk ukhuwah wathaniyah (persaudaraan kebangsaan) dihasilkan melalui proses refleksi kalangan NU. Terdapat tiga faktor yang melatarbelakangi penafsiran NU mengenai toleransi terhadap

Dalam pandangan Khamami Zada, Wakil Ketua LAKPESDAM PBNU, toleransi kepada non-muslim adalah kewajiban agama. Umat muslim dilarang untuk memusuhi non- non-mulsim, pertama, untuk membangun persaudaraan atas dasar kemanusiaan. Kedua, toleransi dilakukan dalam konteks muamalah. Ketiga, untuk mewujudkan risalah Islam sebagai agama rahmatan lil-aalamin (kedamaian bagi semesta alam).

Muslim karena perbedaan agamanya. Umat muslim harus bersama-sama menghargai, menghormati, dan bahkan bekerjasama dengan non-muslim (Wawancara dengan Peneliti, 17 
Maret 2020). Sedangkan menurut Helmy Faishal Zaini, Sekretaris Jenderal Pengurus Besar Nahdlatul Ulama (PBNU), menghormati orang non-muslim itu adalah sama dengan menghormati sesama umat Islam (Wawancara dengan Peneliti, 29 Januari 2019).

Di kalangan NU itu dikenal dan dikembangkan tiga bentuk ukhuwah, yaitu (1) ukhuwah islamiyah, yakni persaudaraan antara umat muslim, (2) ukhuwah wathaniyah, yakni persaudaraan kebangsaan, berbeda agama tapi satu bangsa, dan (3) ukhuwah insaniyah atau ukhuwah basyariyah, yaitu persaudaraan kemanusiaan. Dalam perkembangannya saat ini, ditambah dua bentuk ukhuwah lagi, yakni ukhuwah Nahdliyah, persaudaraan sesama warga NU, dan ukhuwah terhadap alam semesta sebagai respon atas perubahan iklim.

Bentuk-bentuk ukhuwah sebagai dasar pemahaman atas toleransi di kalangan NU dijelaskan oleh Sarmidi, Sekretaris Lembaga Bahtsul Masail PBNU, sebagai berikut:

"Ukhuwah Islamiyah itu persaudaraan antarmuslim, sesama muslim harus bersaudara, tidak boleh saling menghujat, dan tidak boleh saling mencaci. Ternyata toleransi berdasarkan ukhuwah Islamiyah saja tidak bisa karena di Indonesia ada yang tidak Islam atau Muslim, maka toleransi atau ukhuwahnya itu pakai ukhuwah insaniyah, yakni sama-sama sebagai makhluk Allah, harus saling menghargai dan saling menjaga. Rasul sendiri pernah mengatakan barang siapa menyakiti dhimmi, yakni orang kafir yang dilindungi, maka itu sama dengan menyakiti Rasul. Itu bentuk dari ukhuwah insaniyah atau basyariyah. Kemudian ukhuwah wathaniyah yaitu sama-sama sebagai satu negara, satu bangsa maka harus bersaudara" (Wawancara dengan Peneliti, 17 Desember 2018).

Dalam konteks toleransi terhadap non-muslim, bentuk ukhuwah yang relevan adalah ukhuwah wathaniyah dan ukhuwah insaniyah. Menurut Alissa Wahid, Sekretaris Lembaga Kemaslahatan Keluarga PBNU, toleransi terhadap non-muslim itu termasuk dalam kategori ukhuwah wathaniyah dan ukhuwah basyariyah. Di Indonesia berarti konteksnya adalah ukhuwah wathaniyah. Misalnya, mengapa Gus Dur memerintahkan Banser menjaga gereja pada misa Natal, hal itu karena bagian dari ukhuwah wathaniyah. Bagi NU itu jihad. Dari kelima ukhuwah di atas yang paling dipentingkan oleh NU adalah ukhuwah wathaniyah karena NU tidak ada masalah dengan ukhuwah Islamiyah. "HTI itu kan tidak ditolak keIslamannya, tapi ditolak agenda mengubah Indonesianya", jelas Alissa (Wawancara dengan Peneliti, 17 Maret 2020).

Meskipun NU dikenal memiliki tradisi toleransi yang sangat kuat, NU juga menekankan batas-batas toleransi terhadap non-muslim dengan sangat jelas. Pada hubungan yang sifatnya muamalah dengan nonmuslim NU mengikuti apa yang diajarkan oleh Nabi, yang hidup berdampingan dengan umat Yahudi dan umat Nasrani secara biasa. Bermuamalah dengan Yahudi dan Nasrani juga biasa. "Rasulullah kan juga begitu, pernah bermuamalah terkait keuangan dengan Yahudi. Lakum dinukum waliyadin saja. Bahkan mengenai Natal NU tidak pernah membahas soal mengucapkan natal. Bagi kiai-kiai NU itu tidak penting. Kiai Said (Said Aqiel Siroj, Ketua Umum PBNU—-pen) bilang, saya yakin saya mengucapkan selamat natal kepada nonmuslim akidah saya masih kuat," jelas Sarmidi (Wawancara dengan Peneliti, 17 Desember 2018).

Berkaitan dengan peran NU Online sebagai media resmi NU dalam memberikan pemahaman mengenai toleransi terhadap nonmuslim di kalangan warga NU adalah dengan mereproduksi argumen-argumen yang pernah dikemukakan oleh para pendahulu NU. Mengajukan juga argumen-argumen baru sesuai zaman, misalnya kenapa tidak perlu khilafah Islamiyah hari ini? Karena memang Islam tidak memandatkan sistem negara yang baku. Sistem negara itu bagian dari urusan bersama yang bisa dipecahkan lewat jalur musyawarah. Secara lebih khusus, Syafiq Ali, Redaktur NU Online menjelaskan mengenai toleransi terhadap non-muslim berikut: 
"Saya kira dalam 30 tahun terakhir pandangan NU terhadap orang nonmuslim sudah jauh bergeser. Kalau dulu banyak sekali orang Islam, orang NU itu punya prasangka gelap terhadap non-muslim karena mereka tidak kenal, mereka hidup di masyarakat yang homogen, sekampung NU semua, muslim semua. Gara-gara Gus Dur mereka kan jadi kenal pastur, kenal biksu, dan mereka ini orangorang baik semua. Kemudian dengan mobilitasnya menyebabkan NU banyak bergaul dengan lintas kelompok yang melahirkan generasi-generasi yang jauh lebih inklusif, termasuk dalam konteks pergaulan antaragama dibanding dengan 30 tahun yang lalu. Saya kira ini membantu. Pengalaman-pengalaman ini yang ditulis. Perspektifnya sangat kuat dengan tulisan-tulisan anak-anak muda di NU" (Wawancara dengan Peneliti, 29 Januari 2019).

NU memang dikenal sebagai organisasi Islam yang moderat dan toleran terhadap kelompok-kelompok minoritas, termasuk kalangan Kristen semenjak NU dipimpin oleh K.H. Abdurrahman Wahid, yang lebih akrab disapa Gus Dur. Sikap yang lebih toleran dan terbuka ditunjukkan oleh tokoh NU Gus Dur, dengan berbagai kontroversinya.

Gus Dur pernah membuat kaget para kiai NU dengan menerima sebagai Ketua Dewan Kesenian Jakarta (DKJ) dan menjadi juri Festival Film Indonesia (FFI), yang menurut para kiai tidak ada relevansinya dengan masalah keagamaan. Gus Dur juga pernah melontarkan ide untuk mengganti ucapan assalamualaikum dalam bahasa Arab menjadi selamat pagi atau siang, dalam bahasa Indonesia.

Ketika terjadi polemik perkawinan antaragama pada tahun 1991, Gus Dur tidak ragu-ragu melawan arus kelompok konservatif dengan menyatakan larangan perkawinan campur agama sama saja dengan mengingkari kenyataan yang ada dalam masyarakat (Feillard, 2017).

\section{Analisis Konteks}

Dalam konteks sejarah mengenai hubungan NU dengan non-muslim (Nasrani) pada awalnya sebenarnya sangat problematik juga, terutama ketika NU masih menjadi partai politik dan terlibat dalam politik praktis. Sebagai pemegang Departemen Agama, tokoh NU yang menjadi Menteri Agama harus bersikap netral terhadap berbagai persoalan toleransi antaragama. Sebagai organisasi Islam, NU pada saat itu sebenarnya anti-Kristenisasi juga. Ketika sebuah majalah Sastra pimpinan HB. Jassin melecehkan agama Islam dengan menampilkan Allah Swt. sebagai manusia biasa dalam sebuah cerita pendek, terjadi demonstrasi besar yang diorganisir oleh Gerakan Pemuda Ansor pada 24 Oktober 1968. Menteri Agama bahkan mengajukan tuntutan terhadap HB. Jassin dihukum (Feillard, 2017).

NU menjadi lebih moderat setelah kembali ke Khittah 1926, berkat pandanganpandangan KH. Ahmad Shiddiq, dan tentu saja Abdurrahman Wahid. Pada Muktamar NU di Situbondo tahun 1984, KH. Ahmad Shiddiq menjelaskan sikap yang patut diteladani, yaitu toleransi (tasamuh), menghargai sikap dan pandangan yang berbeda berkaitan dengan permasalahan sosial maupun kultural. Menurut KH. Shiddiq, Islam tidak membenarkan sikap ekstrim dan sikap berlebih-lebihan.

Pemahaman NU mengenai toleransi terhadap non-muslim memang bisa dipahami dalam konteks sebagai bentuk dari persaudaraan kemanusiaan (ukhuwah insaniyah/ukhuwah basyariyah) dan persaudaraan kebangsaan (ukhuwah wathaniyah). Dalam ukhuwah insaniyah konteksnya sangat luas tidak hanya dalam wilayah NKRI saja tetapi juga seluruh dunia NU tetap menjaga toleransi dengan pemeluk agama lain. Dalam pandangan NU, ukhuwah insaniyah/ukhuwah basyariyah (persaudaraan kemanusiaan) sebagai bentuk pemahaman mengenai toleransi terhadap non-muslim dapat diwujudkan dengan saling menghargai hak setiap manusia, saling membantu, bertindak adil dan tidak berbuat dzalim kepada manusia lain.

Pemahaman toleransi terhadap nonmuslim sebagai ukhuwah insaniyah tersebut dicetuskan dalam keputusan Komisi Bahtsul 
Masail pada Konferensi NU Wilayah Jawa Timur tahun 2018 di Pondok Pesantren Lirboyo Kediri. Dalam keputusan tersebut dinyatakan latar belakang agama yang berbeda tidak boleh digunakan sebagai alasan untuk berbuat tidak baik, saling memusuhi dan memerangi pengikut agama lain. Maka dari itu, dasar relasi antara umat muslim dan non-muslim, bukan peperangan dan pertikaian, tetapi hubungan yang dilandasi dengan perdamaian dan hidup bersama dengan saling menghormati.

Pemahaman NU mengenai toleransi terhadap non-muslim sebagai wujud ukhuwah wathaniyah atau tata hubungan sesama berkaitan dengan persaudaraan se-bangsa dan se-tanah air. Tata hubungan ini mencakup masalah-masalah yang berkaitan dengan muamalah (sosial, politik, budaya). Dalam konteks muamalah ini setiap warga negara mempunyai derajat dan tanggung jawab yang sama dalam mengusahakan kesejahteraan hidup secara bersama-sama. Dalam Muktamar NU ke-29 di Cipasung Tasikmalaya, 4 Desember 1994, diputuskan bahwa wawasan NU tentang Pluralitas Bangsa disebutkan bahwa sikap toleransi yang berkaitan dengan ukhuwah wathaniyah meliputi:

a. Sikap akomodatif: bersedia mengakomodasi berbagai kepentingan, pandangan dan aspirasi dari berbagai kalangan.

b. Sikap selektif: cerdas dan kritis dalam menentukan kepentingan yang terbaik dan yang bermanfaat (ashlah) dan bermanfaat (anfa') dari pilihan-pilihan yang tersedia.

c. Sikap integratif: bersedia menyesuaikan, menyerasikan dan menyeimbangkan kepentingan-kepentingan dan aspirasi secara tepat, adil, dan seimbang.

d. Sikap Kooperatif: bersedia untuk hidup berdampingan dan bekerja bersama dengan siapapun dalam konteks muamalah dan bukan pada konteks ibadah.

Meskipun demikian, NU juga menentukan batas-batas toleransi dan menjaga kerukunan dengan pengikut umat beragama lain yang dalam praktiknya dilarang melewati batasbatas yang ditentukan, yaitu:

a. Tidak melanggar batas akidah sehingga terperosok dalam kekufuran seperti mengikuti ritual agama lain yang bertujuan mensyiarkan kekufuran. b. Tidak melanggar batas syariat sehingga terperosok dalam hal yang diharamkan, seperti menggunakan simbol-simbol yang serupa dengan agama lain yang bertujuan menyemarakkan hari raya agama lain.

Secara kontekstual, pemahaman NU mengenai toleransi terhadap non-muslim sebagai ukhuwah wathaniyah tidak bisa dilepaskan dari keinginan NU untuk menjaga keutuhan NKRI dan membangun masa depan bangsa Indonesia secara maju dan adil. Dalam keputusan Komisi Bahtsul Masail Konferensi NU Wilayah Jawa Timur, di Pondok Pesantren Lirboyo Kediri, 2018 dinyatakan bahwa Indonesia sebagai bangsa dipersatukan karena keinginan, cita-cita, serta tekad yang sangat kuat untuk membangun masa depan dan kehidupan bersama-sama sebagai sesama warga negara dalam naungan Negara Kesatuan Republik Indonesia (NKRI). Setiap elemen dari bangsa Indonesia dipersatukan dan meleburkan diri dalam sebuah ikatan kebangsaan atau persaudaraan kebangsaan (ukhuwah wathaniyah), yang terbebas dari latar belakang agama dan primordial lainnya yang berbeda.

Faktor yang menentukan penafsiran NU tentang toleransi terhadap non-muslim adalah kepentingan kesatuan bangsa agar tetap utuh. Untuk itu bagi NU menjaga kerukunan antarpengikut beragama dalam konteks berbangsa dan bernegara sangat dibutuhkan untuk mencapai cita-cita bersama yaitu kesatuan nasional dan integritas NKRI. Meskipun demikian, NU juga memberikan batasan-batasan bagi umat Islam dalam bertoleransi terhadap non-muslim. Umat Islam tidak diperbolehkan melanggar batas-batas akidah dan syariat, agar keimanan dan keislamannya dapat dijaga, dan tidak tercampur dengan kekufuran.

Dalam pandangan pengurus dan aktivis NU seperti Khamami Zada dan Alissa Wahid, kepentingan utama $\mathrm{NU}$ adalah kepentingan kebangsaan. Toleransi adalah persoalan bangsa menyangkut hidup bersama antar agama, etnik, dan golongan. Jika tidak ada toleransi kebangsaan, maka bangsa kita akan terpecahpecah. Kalaupun ada kepentingan politik, lebih pada politik kebangsaan, karena politik kebangsaan NU itu adalah kembali ke mu'ahadah wathaniyah (kesepakatan kebangsaan), dalam bentuk penerimaan Pancasila sebagai ideologi bersama yang disepakati seluruh elemen bangsa Indonesia. 
Menurut Alissa Wahid, NU sangat merasa bahwa NU adalah investor terbesar pendirian bangsa Indonesia. Negara Indonesia yang diwariskan oleh para masyayikh (para ulama terdahulu) itulah yang kemudian dipegang benar oleh NU sampai sekarang. "Valuenya orang NU itu kan setia kepada kiainya. Justru itu yang lebih kuat. Misalnya banyak Banser (Barisan Serbaguna Pemuda Ansor) tidak begitu paham mengapa harus menjaga gereja. Oke kalau harus rukun, tapi kan... masih ada tapinya. Tapi karena ini warisan dari Gus Dur mereka akan lakukan" (Wawancara dengan Peneliti, 17 Maret 2020).

\section{Proses Distansiasi dalam Penafsiran}

Penafsiran atau interpretasi, yang menjadi fokus kajian hermeneutika, dalam Ilmu Komunikasi menjadi salah satu syarat suatu tindakan disebut sebagai komunikasi, selain penciptaan pesan. Hermeneutika dalam ranah komunikasi tergolong dalam perspektif interpretif bersama dengan tradisi fenomenologi (Littlejohn, 2002).

Sebagai sebuah tradisi pemikiran, hermeneutika mengkaji mengenai proses pemahaman untuk menafsirkan pesan-pesan komunikasi dalam bentuk teks. Gagasan pokoknya adalah mewujudkan diskursus dalam bentuk teks. Maka dari itu, dalam komunikasi hermeneutika tempatnya adalah bahasa, khususnya bahasa tulis. Sebuah karya tulis menjadikan teks otonom dan terlepas dari cakrawala maksud pembuat atau pengirimnya. Dengan demikian maksud dari teks tidak lagi sesuai dengan apa yang dimaksud oleh pembuatnya (Ricoeur, 2006).

Dalam otonomi teks, terdapat kemungkinan makna teks yang disampaikan dapat terlepas dari maksud pembuatnya. Dengan demikian ia membukakan dirinya pada sejumlah pembacaan yang lebih luas dan tidak terbatas, yang mana pembacaan itu berada dalam konteks sosial budaya yang tidak sama. Jadi, sebuah teks mesti dapat 'membebaskan' dirinya dari konteks sehingga ia bisa 'dikontekstualisasikan' dalam situasi dan kondisi yang berbeda. Pada proses inilah kemudian terjadi apa yang disebut distansiasi.

Distansiasi adalah pemisahan dari dunia dikursus dari konteks dan intensi pembicara struktur kata tertulis dan dari pembaca (Tan et al., 2009). Distansiasi (distanctiation) terjadi ketika individu secara aktif menafsirkan sendiri tekstual dan nontekstual dari sistem simbolik (bahasa) (Petrovici, 2013). Dalam praktiknya, distansiasi terjadi dalam proses penafsiran, ketika bahasa berubah menjadi diskursus, yang disebut sebagai distansiasi pertama, dan ketika diskursus berubah menjadi teks (tekstualitas), yang merupakan distansiasi kedua (Hardiman, 2018).

Hasil kajian ini menunjukkan adanya praktik distansiasi sebagaimana yang dikemukakan oleh Ricoeur, Tan, dkk, dan Petrovoci dalam proses penafsiran terhadap isu toleransi terhadap non-muslim yang dilakukan oleh NU. Sebagai organisasi Islam moderat di Indonesia, NU menafsirkan dan memahami toleransi terhadap non-muslim dengan menjadikan teks secara otonom dan bebas, serta melakukan distansiasi teks dengan penafsiran yang mereka lakukan. Praktik distansiasi melalui proses di mana NU menafsirkan toleransi terhadap non-muslim dengan merujuk kepada bahasa (ayat) atau pesan dalam bentuk bahasa lita'arafu (supaya saling mengenal) dalam surat al-Hujurat ayat 15. NU menafsirkannya bahasa lita'arafu tersebut dengan ukhuwah wathaniyyah (sebagai bentuk persaudaraan sebangsa dan setanah air).

Dalam proses penafsiran yang melahirkan pemahaman atas sebuah teks atau tindakan, berdasarkan teori interpretasi Ricoeur, maka prosesnya tidak berhenti pada hasil dari penafsiran itu sendiri. Tetapi menjadikan hasil penafsiran itu kemudian diambil dan dijadikan sebagai identitas diri (pendakuan), karena pada dasarnya penafsiran itu dilakukan dengan refleksi yang mendalam berdasarkan pengalaman dan dialektika dengan penafsiran kelompok-kelompok lain, termasuk dengan kekuasaan.

NU sebagai organisasi Islam moderat di Indonesia melakukan dua tindakan penafsiran (double hermeneutics). Pertama, NU melakukan penafsiran dengan melakukan refleksi atas makna-makna yang berkaitan dengan toleransi terhadap non-muslim. Kedua, NU menjadikan hasil penafsiran reflektif tersebut sebagai pendakuan yang merupakan ujung dari proses penafsiran itu sendiri (hermeneutical arch) (Tan et al., 2009). Melalui pendakuan ini, hasil penafsiran yang mereka lakukan dijadikan rujukan untuk melakukan tindakan atau dikontestasikan dengan pemahaman kelompok-kelompok lain yang 
memiliki pemahaman yang berbeda di berbagai bentuk ranah publik (public sphere).

Salah satu bentuk pendakuan NU berkaitan dengan ukhuwah wathaniyah sebagai hasil penafsiran mengenai toleransi terhadap non-muslim pada konteks kekinian adalah keinginan NU untuk mempertahankan persatuan Negara Kesatuan Republik Indonesia (NKRI) dan membangun masa depan bangsa Indonesia secara maju dan adil. Keutuhan dan masa depan NKRI yang lebih baik bagi NU menjadi pertimbangan utama di tengah wacana bubarnya NKRI pada tahun 2030, yang diwacanakan oleh salah satu kandidat calon presiden pada Pemilu 2019 (Haryono, 2019).

Sebagai organisasi Islam yang berpengaruh di Indonesia, NU memandang toleransi terhadap non-muslim merupakan hal yang alamiah (sunnatullah) dalam kehidupan. NU tidak memusuhi, alih-alih memerangi nonmuslim, meskipun umat Islam di Indonesia mayoritas. Hal ini berbeda dengan kelompokkelompok radikal lain seperti HTI, Laskar Jihad, dan FPI yang menganggap non-muslim adalah kaum kafir yang mesti dimusuhi, atau bahkan diperangi.

NU sangat toleran terhadap nonmuslim, sebagaimana pemahaman mereka mengenai toleransi terhadap non-muslim, NU lebih memahami toleransi dalam konteks keIndonesia-an, yakni sebagai ukhuwah wathaniyah (persaudaraan kebangsaan). NU sangat mengutamakan kesatuan dan kemajuan bangsa dan negara Indonesia. Sikap teguh menjaga persatuan bangsa secara historis ditunjukkan oleh KH. Wahid Hasyim, putera KH. Hasyim Asy'ari, pendiri NU, saat menentukan dasar Negara Indonesia pada awal kemerdekaan. Menurut Feillard, pada situasi yang kritis ini NU sebagai organisasi Islam berusaha menemukan solusi bersama agama lainnya untuk mempertahankan persatuan bangsa (Feillard, 2017).

Dalam pandangan NU toleransi adalah sunnatullah sebagai keniscayaan atas pluralitas bangsa Indonesia yang beragam. NU ingin menjadikan Islam sebagai agama yang memberikan kerahmatan bagi alam semesta (rahmatan lil-'alamin). Sikap toleran NU ditunjukkan oleh tokoh-tokoh NU seperti Abdurrahman Wahid, Hasyim Muzadi, Mustofa Bisri, dan Said Aqiel Siraj, serta tokohtokoh NU lainnya. Pemahaman NU yang moderat dan toleran terhadap non-muslim ini juga relevan dengan gagasan Islam Nusantara yang memang bercirikan moderat dan toleran sebagai warisan para Walisongo (Sembilan Wali yang menyebarkan Islam di Jawa). Selaras juga dengan ajaran Aswaja, sebagai manifestasi Islam asli Indonesia (Murtaufiq, 2018).

Implikasi teoritik dari penggunaan konsep distansiasi dari Teori Interpretasi Ricoeur adalah menunjukkan adanya keberlakuan konsep distansiasi tersebut dalam proses penafsiran mengenai toleransi terhadap non-muslim yang merujuk pada bahasa litaarafu. Distansiasi atau penjarakan merupakan upaya memahami teks dengan menjadikan teks otonom, yakni adanya ketidaktergantungan makna teks dari maksud pengarangnya. Temuan penelitian ini menunjukkan adanya proses distansiasi dalam proses komunikasi mengenai toleransi terhadap non-muslim yang dilakukan NU.

\section{Hermeneutika sebagai Kritik}

Hermeneutika sebagai kritik (ideologi) berarti menjadikan hermeneutika tidak sebatas pada penafsiran atau pemahaman atas teks atau bahasa semata. Tapi lebih jauh dengan menjadikan hasil penafsiran itu sebagai kritik atas pemahaman teks yang dianggap terdistorsi, atau pemahaman dominan yang selama ini dianggap benar (taken for granted).

Hermeneutika sebagai kritik ideologi ini digagas oleh Ricoeur untuk menyatukan perbedaan pandangan hermeneutika filosofis yang dipelopori Gadamer dengan kritik ideologi yang digagas oleh Habermas mengenai tradisi yang melingkupi pemahaman. Gadamer tidak sependapat dengan Habermas soal emasipatori dan kritik ideologi (Gadamer, 1975). Sebaliknya, Habermas juga menyoal tradisi yang tidak dianggap sebagai kepentingan dalam proses penafsiran (Ricoeur, 2006). Dalam pandangan Ricoeur, keduanya sebenarnya bisa saling mengakui klaim universalitasnya dengan cara menentukan tempat pihak yang satu di dalam struktur pihak yang lain. Oleh karena itu Ricoeur dalam upayanya mencari titik antara keduanya mengajukan gagasannya untuk menjadikan hermeneutika sebagai kritik ideologi.

Hermeneutika atau penafsiran sebagai kritik ideologi dapat dilakukan dengan menjadikan tradisi hermeneutika untuk Teori Kritis. Hermeneutika sebagai kritik ideologi 
adalah dengan menggunakan hermeneutika sebagai tradisi untuk berkomunikasi dan memahami subyek dengan lingkaran hermeneutika verstehen (memahami) (Wolff, 1975). Dalam konteks yang lain, memahami hermeneutika sebagai kritik ideologi berarti menjadikan hermeneutika indoktrinasi, sebagai analogi dari konteks naratif, yang merupakan lawan dari hermeneutika edukasi (Lammi, 1997).

Dalam praktiknya, hermeneutika sebagai kritik ideologi dapat merujuk pada gagasan hermeneutika otoritatif dari Khaled M. Abou el-Fadl sebagai kritik atas penafsiran otoritatif terhadap pemikiran Islam. Penafsiran otoritatif adalah penafsiran atas nama Tuhan yang dianggap mutlak kebenarannya dengan mengabaikan aspek-aspek lainnya seperti keadilan dan kemanusiaan (Nasrullah, 2008). Hermeneutika sebagai kritik ideologi juga dapat digunakan sebagai sebagai acuan kritik ideologi sejarah Orde Baru, berkaitan dengan penafsiran sejarah transisi pemerintahan dari kekuasaan Orde Lama beralih ke Orde Baru yang memiliki berbagai versi (Seran, 2015).

Kajian ini menemukan bahwa NU memahami toleransi terhadap non-muslim sebagai ukhuwah wathaniyah tersebut dapat dijadikan sebagai kritik atas pandangan dunia (world view) dari kelompok-kelompok Islam radikal mengenai toleransi terhadap nonmuslim. Pandangan-pandangan mereka yang intoleran, yang tidak menghargai perbedaan agama, dan bahkan memusuhi agama dan kelompok-kelompok kepercayaan lain. Dasar kritik NU adalah karena toleransi terhadap nonmuslim dipahami NU lebih dalam konteks kebangsaan atau ke-Indonesiaan yakni ukhuwah wathaniyah dalam wujud persaudaraan kebangsaan, yang tidak memandang pada latar belakang keagamaan dan kepercayaannya, serta tidak melihat latar belakang sektarian lainnya.

NU memandang bahwa kelompokkelompok dengan ideologi radikal yang intoleran terhadap non-muslim sama halnya mereka tidak mendukung terjaganya NKRI. Pandangan sekaligus kritik ideologi NU ini sebagaimana ditegaskan dalam keputusan Komisi Bahtsul Masail pada Konferensi NU Wilayah Jawa Timur di Pondok Pesantren Lirboyo Kediri, tahun 2018. Dalam keputusan tersebut dinyatakan latar belakang agama yang berbeda tidak boleh digunakan sebagai alasan untuk berbuat tidak baik, saling memusuhi dan memerangi pengikut agama lain. Maka dari itu, dasar relasi antara umat muslim dan nonmuslim, bukan peperangan dan pertikaian, tetapi hubungan yang dilandasi dengan perdamaian dan hidup bersama dengan saling menghormati.

Penafsiran pemahaman NU tentang toleransi terhadap non-muslim sebagai ukhuwah wathaniyah pada prinsipnya merupakan upaya NU sebagai Organisasi Islam moderat untuk menghapus pandangan bahwa Islam itu anti-toleransi. Dengan pemahaman tersebut NU, sebagai organisasi Islam moderat di Indonesia secara internal memiliki kesadaran untuk bersama-sama membangun Indonesia. Sekaligus secara eksternal menjadikannya sebagai kritik dan kontra-diskursus atas pemahaman dan pandangan kelompokkelompok Islam radikal bahwa non-muslim itu harus dijauhi, dimusuhi, bahkan diperangi.

Dalam pemahaman NU, non-muslim adalah saudara sesama manusia dan saudara sesama bangsa. Pemahaman NU bahwa nonmuslim adalah setara karena sebagai saudara sebangsa selaras dengan perjuangan etnis Tionghoa, etnis yang selalu dibela oleh Gus Dur, melalui Perhimpunan Indonesia Tionghoa (INTI) yang berusaha membangun relasi dan kesamaan hak dan solidaritas untuk memperoleh pengakuan dari individu-individu kelompok lain sebagai sesama warga negara Indonesia (Marta, 2018).

Secara historis, NU menjadi organisasi yang lebih moderat dan toleran setelah kembali ke Khittah 1926, yang ditandai keluarnya NU dari Partai Persatuan Pembangunan (PPP). Pandangan NU yang lebih moderat dan toleran ini berkat gagasangagasan dari KH. Ahmad Siddiq, dan tentu saja Abdurrahman Wahid (Gus Dur), yang keduanya dipilih menjadi ketua Syuriah dan Tanfidziyah NU pada Muktamar NU tahun 1984 di Situbondo, Jawa Timur.

KH. Ahmad Shiddiq menjelaskan sikap yang patut diteladani, yaitu toleransi (tasamuh) menghargai sikap dan pandangan yang berbeda berkaitan dengan permasalahan sosial maupun kultural. Menurut KH. Ahmad Shiddiq, Islam tidak membenarkan sikap ekstrim dan sikap berlebih-lebihan. Menurut Martin van Bruinessen, Kiai Shiddiq dan Gus Dur membawa ide-ide yang berbeda dengan para pemimpin-pemimpin NU terdahulu 
tentang apa yang mesti diperjuangkan NU (Van Bruinessen, 2008). Ketika terjadi polemik perkawinan antaragama pada tahun 1991, Gus Dur tidak ragu-ragu melawan arus kelompok konservatif dengan menyatakan larangan perkawinan campur agama sama saja dengan mengingkari kenyataan yang ada dalam masyarakat (Feillard, 2017).

NU sebagai organisasi Islam dengan toleransi terhadap non-muslim yang kuat semakin menonjol saat dipimpin oleh Gus Dur. Semasa memimpin NU Gus Dur dikenal sangat dekat dengan tokoh-tokoh dan pemuka-pemuka agama non-Islam. Bahkan dikenal pula sebagai pembela kelompok-kelompok minoritas, baik secara etnis maupun agama.

Meskipun demikian, dalam perkembangannya saat ini, moderatisme dan toleransi NU terhadap kelompok lain juga mulai dipertanyakan, sekaligus mendapat tantangan baik secara internal maupun ekternal. Secara eksternal mulai muncul otoritas Islam baru di luar tokoh-tokoh mainstream NU maupun Muhammadiyah, melalui tokoh-tokoh seperti Abdullah Gymnastiar (Aa' Gym), Yusuf Mansyur, Bakhtiar Nasir, dan Felix Siauw, serta beberapa tokoh lainnya seperti Habib Rizieq Shihab. Di samping itu secara internal dari kalangan NU sendiri juga muncul kiai-kiai popular tetapi memiliki pandangan konservatif yang menolak gagasan-gagasan Gus Dur mengenai toleransi, moderat, dan inklusi, seperti Idrus Ramli, Buya Yahya, dan Abdul Somad (Arifianto, 2018).

Bahkan keterlibatan tokoh-tokoh NU lokal dalam penyerangan terhadap kelompok Ahmadiyah yang dianggap sektarian karena Syiah juga dipertanyakan. Keterlibatan tokohtokoh lokal itu tentu dapat mendelegitimasi tokoh-tokoh NU yang dikenal sebagai tokoh yang pluralis (Kayane, 2020). Fenomena ini menunjukkan satu sisi dalam tubuh NU sendiri banyak faksi dan kepentingan, di sisi lainnya hal itu juga menunjukkan bahwa tantangan terhadap upaya-upaya menumbuhkan civil Islam di Indonesia melalui organisasiorganisasi Islam moderat seperti NU dan Muhammadiyah masih kuat dan tidak pernah surut (Hefner, 2016).

Implikasi teoritik kajian ini adalah hermeneutika, seperti diinginkan Ricoeur tidak sekadar dan berhenti pada penafsiran tapi dapat dijadikan sebagai kritik ideologi yang di dalamnya mengandung kesadaran palsu (false consciousness). Melalui penafsiran atas teksteks (bahasa) yang berhubungan dengan toleransi terhadap non-muslim, hasilnya dijadikan sebagai kritik ideologi terhadap ideologi Islam radikal yang memiliki pandangan dan pemahaman radikal yang cenderung intoleran.

Di sisi lain, temuan kajian ini memperkuat pandangan mengenai NU sebagai organisasi Islam moderat dan toleran yang mengikuti ajaran Aswaja. Penafsiran NU mengenai toleransi terhadap non-muslim sebagai ukhuwah wathaniyah (persaudaraan kebangsaan), di mana dalam pandangan NU non-muslim merupakan saudara sebangsa membuktikan NU adalah organisasi Islam moderat. Hal ini relevan dengan kajian-kajian sebelumnya tentang moderatisme NU (Burhani, 2012; Hannase, 2017; Hilmy, 2013; Murtaufiq, 2018).

\section{SIMPULAN}

Perspektif hermeneutika Ricoeur mengenai toleransi terhadap non-muslim di kalangan NU menunjukkan bahwa NU menafsirkan toleransi terhadap non-muslim sebagai persaudaraan sebangsa dan setanah air (ukhuwah wathaniyah). Pemahaman NU ini dalam proses distansiasi (penjarakan) merujuk pada al-Qur'an surat al-Hujurat ayat 13, khususnya pada teks atau bahasa lita'arafu. Secara tekstual wawasan NU tentang Pluralitas Bangsa ini, yang di dalamnya memuat sikap NU tentang toleransi, diputuskan dalam Keputusan Muktamar NU ke-29 tahun 1994 di Cipasung Tasikmalaya.

Dalam praktik penafsirannya, pemahaman NU mengenai toleransi terhadap non-muslim sebagai persaudaraan sebangsa dan setanah air (ukhuwah wathaniyah) dilatarbelakangi oleh beberapa faktor. Pertama, untuk membangun persaudaraan atas dasar kemanusiaan. Kedua, toleransi dilakukan dalam konteks muamalah. Ketiga, untuk mewujudkan risalah Islam sebagai agama rahmatan lilaalamin (kedamaian bagi semesta alam).

Secara kontekstual pemahaman NU didasarkan persaudaraan se-bangsa dan setanah air. Tata hubungan ini mencakup masalah-masalah yang berkaitan dengan muamalah (sosial, politik, budaya). Dalam konteks muamalah ini setiap warga negara 
mempunyai derajat dan tanggung jawab yang sama dalam mengusahakan kesejahteraan hidup secara bersama-sama.

Penafsiran NU mengenai toleransi terhadap non-muslim sebagai persaudaraan sebangsa dan setanah air (ukhuwah wathaniyah), merupakan subyektifitas NU dalam menafsirkan toleransi. Sekaligus kemudian menjadi pemahaman (pendakuan) NU yang diwujudkan dalam bentuk keinginan NU untuk menjaga keutuhan NKRI dan membangun masa depan bangsa Indonesia secara maju dan adil. Selain itu, penafsiran ini juga dapat dijadikan kritik atas pemahaman kelompok-kelompok Islam radikal mengenai toleransi terhadap non-muslim yang cenderung eksklusif. Bagi NU, non-muslim adalah saudara yang diikat atas kesadaran kebangsaan dan kenegaraan.

\section{DAFTAR PUSTAKA}

Al Qurtuby, S. (2013). Peacebuilding in Indonesia: Christian-Muslim Alliances in Ambon Island. Islam and ChristianMuslim Relations, 24(3), 349-367. https://doi.org/10.1080/09596410.2013.7 85091

Arifianto, A. R. (2017). Practicing What It Preaches? Understanding the Contradictions between Pluralist Theology and Religious Intolerance within Indonesia's Nahdlatul Ulama. AlJami'ah: Journal of Islamic Studies, 55(2), 241-264. https://doi.org/10.14421/ajis.2017.552.24 $1-264$

Arifianto, A. R. (2018). Quo Vadis Civil Islam? Explaining Rising Islamism in Post Reformasi Indonesia. Kyoto Review of Southeast Asia, 24. https://kyotoreview.org/issue-24/risingislamism-in-post-reformasi-indonesia/

Arifin, B. (2016). Implikasi Prinsip Tasamuh (Toleransi) dalam Interaksi Antarumat Beragama. Fikri, volume 1, 391-420.

Arifin, Z., \& Yu'timaalahuyatazaka, Y. (2017). Persepsi Santri dan Kiai terhadap Pluralisme Agama di Pendidikan Ulama Tarjih Muhammadiyah (PUTM) dan Aswaja Nusantara Yogyakarta. Al-Tahrir: Jurnal Pemikiran Islam, 17(1), 179-203. https://doi.org/10.21154/altahrir.v17i1.72
2

Assyaukanie, L. (2013). Contemporary Developments in Indonesian Islam: Explaining the 'Conservative Turn.' Bulletin of Indonesian Economic Studies, 49(3), 394-395. https://doi.org/10.1080/00074918.2013.8 50644

Azra, A. (2005). 1. Islamic Thought: Theory, Concepts, and Doctrines in the Context of Southeast Asian Islam. In K. S. Nathan \& M. Hashim Kamali (Eds.), Islam in Southeast Asia (pp. 3-21). ISEAS-Yusof Ishak Institute Singapore. https://doi.org/10.1355/9789812306241003

Bakar, A. (2015). Konsep Toleransi Dan Kebebasan Beragama. Toleransi, 7(2), 123-131. https://doi.org/10.24014/trs.v7i2.1426

Barton, G. (2014). The Gülen Movement, Muhammadiyah and Nahdlatul Ulama: Progressive Islamic Thought, Religious Philanthropy and Civil Society in Turkey and Indonesia. Islam and ChristianMuslim Relations, 25(3), 287-301. https://doi.org/10.1080/09596410.2014.9 16124

Bryman, A. (2012). Social research methods Bryman. OXFORD University Press. https://doi.org/10.1017/CBO9781107415 324.004

Burhani, A. N. (2012). Al-Tawassut wa-l I'tidāl: The NU and moderatism in Indonesian Islam. Asian Journal of Social Science, 40(5-6), 564-581. https://doi.org/10.1163/1568531412341262

Crouch, M. (2011). Asia-Pacific:Ahmadiyah in Indonesia: A history of religious tolerance under threat? Alternative Law Journal, 36(1), 56-57. https://doi.org/10.1177/1037969X110360 0115

Feillard, A. (2017). NU vis a vis Negara: Pencarian Isi, Bentuk, dan Makna. Yogyakarta: IRCiSoD dan LKiS.

Gadamer, H. G. (1975). Hermeneutics and social science. Philosophy \& Social Criticism, 2(4), 307-316. https://doi.org/10.1177/01914537750020 0402

Gunawan, H. (2015). Toleransi beragama menurut pandangan hamka dan nurcholis 
madjid. Fakultas Agama Islam Universitas Muhammadiyah Surakarta.

Hannase, M. (2017). Explaining Doctrines of Indonesia's Islamic Organization of Nahdlatul Ulama (NU) from the Perspective of Islamic Radical Groups. Istiqro', 15(02), 475-496.

Hardiman, F. B. (2018). Seni Memahami Hermeneutika dari Schleiermacher sampai Derrida (4th ed.). Yogyakarta: Kanisius.

Haryono, C. G. (2019). Genealogi Wacana Pada Pesan Agitatif Pidato Prabowo Subiyanto Tentang Nkri Bubar Tahun 2030. Bricolage: Jurnal Magister Ilmu Komunikasi, 5(1), 31-48.

Hefner, R. W. (2013). the Study of Religious Freedom in Indonesia. Review of Faith and International Affairs, 11(2), 18-27. https://doi.org/10.1080/15570274.2013.8 08038

Hefner, R. W. (2016). Public Islam and the Problem of Democratization. In R. Blaug \& J. Schwarzmantel (Eds.), Democracy (pp. 516-521). Columbia University Press. https://doi.org/10.7312/blau17412107

Hefner, R. W. (2017). Christians, Conflict, and Citizenship in Muslim-Majority Indonesia. The Review of Faith \& International Affairs, 15(1), 91-101. https://doi.org/10.1080/15570274.2017.1 284403

Hilmy, M. (2013). Whiter Indonesia's Islamic Moderatism? A Reexamination on the Moderate Vision of Muhammadiyah and NU. JOURNAL OF INDONESIAN ISLAM, 7(1), 24. https://doi.org/10.15642/JIIS.2013.7.1.24 $-48$

Jamrah, S. A. (2015). Toleransi Antarumat Beragama: Perspektif Islam. Jurnal Ushuluddin, 23(2), 185-200.

Kayane, Y. (2020). Understanding Sunni-Shi'a sectarianism in contemporary Indonesia: A different voice from Nahdlatul Ulama under pluralist leadership. Indonesia and the Malay World, 48(140), 78-96. https://doi.org/10.1080/13639811.2020.1 675277

Kinsella, E. A. (2006). Hermeneutics and critical hermeneutics: Exploring possibilities within the art of interpretation. Forum Qualitative
Sozialforschung, 7(3).

Lammi, W. (1997). The hermeneutics of ideological indoctrination. Perspectives on Political Science, 26(1), 10-14. https://doi.org/10.1080/10457099709600 658

Littlejohn, S. . (2002). Theories of Human Communication (7th ed.). Belmont, CA: Wadsworth-Thomson Learning.

Magnis-Suseno, F. (2016). F. Budi Hardiman, Seni Memahami Hermeneutik dari Schleiermacher sampai Derrida. DISKURSUS - Jurnal Filsafat Dan Teologi STF Driyarkara, 15(1), 95-97. https://doi.org/10.26551/diskursus.v15i1. 51

Maksum, A., Febrianto, P. T., \& Wahyuni, E. N. (2019). Interpretation of democracy, pluralism and tolerance among the young activists of Muhammadiyah and Nahdlatul Ulama. Masyarakat, Kebudayaan Dan Politik, 32(3), 275. https://doi.org/10.20473/mkp.v32i32019. 275-289

Manan, A. (2016). Diskursus Fatwa Ulama tentang Perayaan Natal. MIQOT: Jurnal Ilmu-Ilmu Keislaman, 40(1), 25-43. https://doi.org/10.30821/miqot.v40i1.213

Marta, R. F. (2018). Perjuangan Multikulturalisme Perhimpunan Indonesia Tionghoa Dalam Perspektif Rekognisi Axel Honneth. Bricolage: Jurnal Magister Ilmu Komunikasi, 4(01), 23-31.

https://doi.org/10.30813/bricolage.v4i01. 1065

Mouritsen, P. (2003). What's the Civil in Civil Society? Robert Putnam, Italy and the Republican Tradition. Political Studies, 51(4), 650-668. https://doi.org/10.1111/j.00323217.2003.00451.x

Mu'ti, A. (2016). Akar Pluralisme dalam pendidikan Muhammadiyah. Afkaruna, 12(1), 1-42. https://doi.org/10.18196/aiijis.2016.0053. $1-42$

Muhtarom, M. (2017). Mempertimbangkan Gagasan Hermeneutika Farid Esack untuk Membangun Kerukunan Hidup Umat Beragama. At-Taqaddum, 7(2), 191-209. https://doi.org/10.21580/at.v7i2.1202

Mursyid, S. (2016). Konsep Toleransi (AlSamahah) Antar Umat Beragama 
Perspektif Islam. Jurnal AQLAM, Journal of Islam and Plurality, 2(1), 35-51.

Murtaufiq, S. (2018). Promoting Islam Nusantara: A Lesson from Nahdlatul Ulama (NU). Al-Insyiroh: Jurnal Studi Keislaman, 2(2), 1-29. https://doi.org/10.35309/alinsyiroh.v2i2.3 319

Nasrullah, N. (2008). Hermeneutika Otoritatif Khaled M. Abou El Fadl: Metode Kritik Atas Penafsiran Otoritarianisme Dalam Pemikiran Islam. HUNAFA: Jurnal Studia Islamika, 5(2), 137. https://doi.org/10.24239/jsi.v5i2.160.137150

Palmer, R. E. (2005). Hermeneutika Teori Baru Mengenai Interpretasi (Masnur Hery \& Damanhuri Muhammad) (II). Yogyakarta: Pustaka Pelajar.

Petrovici, I. (2013). Philosophy as Hermeneutics. The World of the Text Concept in Paul Ricoeur's hermeneutics. Procedia - Social and Behavioral Sciences, 71, 21-27. https://doi.org/10.1016/j.sbspro.2013.01. 004

Radford, G. P. (2005). On The Philosophy of Communication. California: Thomson Wadsworth.

Ricoeur, P. (2006). Hermeneutika Ilmu Sosial (Muhammad Syukri). Yogyakarta: Kreasi Wacana.

Ridwan, R. (2020). The Role of Nahdlatul Ulama (NU) in Maintaining Religious Tolerance in Papua: Some Observations. Journal of Nahdlatul Ulama Studies, 1(1), 17-33. https://doi.org/10.35672/jnus.v1i1.2

Safrodin, S. (2019). Diskursus Naskh AyatAyat Toleransi Oleh Ayat-Ayat Perang Dalam Al-Qur'an. Jurnal THEOLOGIA, 30(1), 51. https://doi.org/10.21580/teo.2019.30.1.32 06

Seran, A. (2015). Hermeneutika sebagai Acuan Kritik Ideologi Sejarah Orde Baru. Respon, 20(02), 145-185.

Tan, H., Wilson, A., \& Olver, I. (2009). Ricoeur's Theory of Interpretation: An Instrument for Data Interpretation in Hermeneutic Phenomenology. International Journal of Qualitative Methods, 8(4), 1-15. https://doi.org/10.1177/16094069090080
0401

Van Bruinessen, M. (2008). NU: Tradisi, Relasi-relasi Kuasa, Pencarian Wacana Baru. Yogyakarta: LKiS.

Wahid, A., \& Taylor, H. (2008). A Tradition of Tolerance in Indonesia Offers Hope. Foreign Service Journal, April, 35-40.

Wolff, J. (1975). Hermeneutics and the Critique of Ideology. The Sociological Review, 23(4), 811-828. https://doi.org/10.1111/j.1467954X.1975.tb00541.x

\section{Wawancara:}

Ali, Syafiq. (29 Januari 2019). Wawancara Pribadi.

Sarmidi. (17 Desember 2018). Wawancara Pribadi.

Wahid, Alissa Qotrunnada Munawaroh. (17 Maret 2020). Wawancara Pribadi.

Zada, Khamami. (17 Maret 2020). Wawancara Pribadi melalui e-mail.

Zaini, Helmy Faishal. (29 Januari 2019). Wawancara Pribadi. 
